Research article

Open Access

\title{
Mouse mammary tumors display Stat3 activation dependent on leukemia inhibitory factor signaling
}

\author{
Ana Quaglino ${ }^{1,2}$, Carolina Schere-Levy ${ }^{1,2}$, Leonardo Romorini ${ }^{1}$, Roberto P Meiss ${ }^{2}$ and \\ Edith C Kordon ${ }^{1,2}$
}

\begin{abstract}
${ }^{1}$ IFIBYNE (CONICET), Facultad de Ciencias Exactas y Naturales, University of Buenos Aires, Argentina
2IIHEMA-IEO, Academia Nacional de Medicina, Buenos Aires, Argentina
\end{abstract}

Corresponding author: Edith C Kordon, ekordon@fbmc.fcen.uba.ar

Received: 5 Apr 2006 Revisions requested: 1 Jun 2006 Revisions received: 7 Sep 2007 Accepted: 10 Oct 2007 Published: 10 Oct 2007

Breast Cancer Research 2007, 9:R69 (doi:10.1186/bcr1777)

This article is online at: http://breast-cancer-research.com/content/9/5/R69

(c) 2007 Quaglino et al.; licensee BioMed Central Ltd.

This is an open access article distributed under the terms of the Creative Commons Attribution License (http://creativecommons.org/licenses/by/2.0), which permits unrestricted use, distribution, and reproduction in any medium, provided the original work is properly cited.

\begin{abstract}
Introduction It has been demonstrated that leukemia inhibitory factor (LIF) induces epithelium apoptosis through Stat3 activation during mouse mammary gland involution. In contrast, it has been shown that this transcription factor is commonly activated in breast cancer cells, although what causes this effect remains unknown. Here we have tested the hypothesis that locally produced LIF can be responsible for Stat3 activation in mouse mammary tumors.

Methods The studies were performed in different tumorigenic and non-tumorigenic mammary cells. The expression of LIF and LIF receptor was tested by RT-PCR analysis. In tumors, LIF and Stat3 proteins were analyzed by immunohistochemistry, whereas Stat3 and extracellular signal-regulated kinase (ERK) $1 /$ 2 expression and phosphorylation were studied by Western blot analysis. A LIF-specific blocking antibody was used to determine whether this cytokine was responsible for Stat3 phosphorylation induced by conditioned medium. Specific pharmacological inhibitors (PD98059 and Stat3ip) that affect ERK $1 / 2$ and Stat3 activation were used to study their involvement in LIF-induced effects. To analyze cell survival, assays with crystal violet were performed.
\end{abstract}

Results High levels of LIF expression and activated Stat3 were found in mammary tumors growing in vivo and in their primary cultures. We found a single mouse mammary tumor cell line, LM3, that showed low levels of activated Stat3. Incidentally, these cells also showed very little expression of LIF receptor. This suggested that autocrine/paracrine LIF would be responsible for Stat3 activation in mouse mammary tumors. This hypothesis was confirmed by the ability of conditioned medium of mammary tumor primary cultures to induce Stat3 phosphorylation, activity that was prevented by pretreatment with LIF-blocking antibody. Besides, we found that LIF increased tumor cell viability. Interestingly, blocking Stat3 activation enhanced this effect in mammary tumor cells.

Conclusion LIF is overexpressed in mouse mammary tumors, where it acts as the main Stat3 activator. Interestingly, the positive LIF effect on tumor cell viability is not dependent on Stat3 activation, which inhibits tumor cell survival as it does in normal mammary epithelium.

\section{Introduction}

The pleiotropic cytokine leukemia inhibitory factor (LIF) is a secreted 38 to $67 \mathrm{kDa}$ glycoprotein first named for its ability to induce macrophage differentiation in the murine myeloid leukemic cell line M1 [1]. This factor has been detected in a variety of adult mouse tissues and displays different biological activities, including effects on bone metabolism, inflammation, neural development and embryogenesis [2]. A potential role for LIF in the pathogenesis of human breast cancer is indicated by its expression in breast cancer cells $[3,4]$, which can

$\mathrm{C} / \mathrm{EBP}=\mathrm{CCAAT}$-enhancer-binding protein; $\mathrm{CM}=$ conditioned medium; $\mathrm{ER}=$ estrogen receptor; ERK = extracellular signal-regulated kinase; FBS = fetal bovine serum; HDT = hormone-dependent tumor; HIT = hormone-independent tumor; IL = interleukin; JAK = Janus kinase; LIF = leukemia inhibitory factor; LIF-D = secreted 'free' form of LIF; LIF-M = extracellular matrix-associated form of LIF; LIF-R = leukemia inhibitory factor receptor; MAPK = mitogen-activated protein kinase; $M E M=$ minimal essential medium; MEK= MAPK/ERK kinase; MMTV=mouse mammary tumor virus; PBS = phosphate-buffered saline; $\mathrm{PR}=$ progesterone receptor; $\mathrm{pY}=$ tyrosine-phosphorylated; $\mathrm{RT}$-PCR = reverse transcriptase-mediated polymerase chain reaction; Stat $=$ signal transduction and activators of transcription; Stat3ip $=$ Stat3-specific inhibitory peptide; TPC $=$ tumor primary culture. 
be modulated by progestins and antiprogestins [5], and by its capacity to induce the proliferation of several estrogendependent (MCF-7 and T47D) and estrogen-independent (SK-BR3 and BT20) breast cancer cell lines as well as fresh breast carcinoma cells $[4,6]$. In spite of these data, little is known about the relevance of LIF for mammary tumor development in vivo.

Biological functions of LIF are mediated by the formation of a cell surface LIF receptor complex between the low-affinity LIF receptor (LIF-R) and a gp130 subunit [7,8]. All the known receptors that contain gp130 have Janus kinase (JAK) kinases (tyrosine kinases) bound to their intracellular tails [9]. After ligand-mediated receptor assembly, the JAKs become activated and phosphorylate cytoplasmic proteins called signal transducer and activators of transcription (Stats). The activated Stats then dimerize, translocate to the nucleus, and participate in transcriptional regulation by binding to specific DNA sites. It has been reported that among the seven members of the Stat family, Stat3 is the major mediator of gp130 signals $[10,11]$.

In the normal mouse mammary gland, Stat3 is pro-apoptotic and a crucial mediator of post-lactational regression. Mammary local factors stimulate the phosphorylation of Stat3 during involution [12], and mammary glands of Stat3 conditional knockout mice showed a suppression of epithelial apoptosis that led to a marked delay in mammary gland involution [13]. However, elevated Stat3 tyrosine phosphorylation and DNAbinding activity have been reported in breast cancer cell lines. In addition, inhibition of the activation of Stat3 blocked the proliferation and survival of those cancer cells [14-16].

It has been established that LIF is the physiological activator of Stat3 during mammary gland involution and has a principal role in the apoptotic process $[17,18]$. In addition, the capacity of LIF to induce Stat3 phosphorylation has been demonstrated in several different experimental models [19-23]. However, no linkage has yet been made between LIF expression and Stat3 activation in mammary tumors. To address this issue, in the present study we evaluated LIF expression and its ability to induce Stat3 tyrosine phosphorylation in mouse mammary tumors. Taking into account the drastic difference in the significance of activation of this transcription factor in neoplastic and normal mammary cells, various tumor lines were assayed and compared with the non-tumorigenic $\mathrm{HC} 11$ cell line. We also studied LIF expression and its ability to induce Stat3 activation in mouse mammary tumor models with different grades of differentiation and malignancy: the non-metastatic mouse mammary tumor virus (MMTV)-induced hormonedependent and hormone-independent neoplasias (HDTs and HITs, respectively) $[24,25]$ and the poorly differentiated highly metastatic LM3 mammary tumor line [26].

\section{Materials and methods \\ Animals}

Female BALB/c mice from our mouse colony, 8 to 12 weeks in age and 20 to $25 \mathrm{~g}$ in weight, were used throughout. They were housed four per cage in conditioned rooms at $20 \pm 2{ }^{\circ} \mathrm{C}$, kept under an automatic 12 hours light/12 hours darkness schedule, and given pellets and tap water ad libitum. All animal studies were conducted in accordance with the NIH Guide for the Care and the Use of Laboratory Animals.

\section{Tumors and cell lines}

The tumors, primary cultures and cell lines used are described in Table 1.

Tumors growing in vivo were removed from mice before reaching $1 \mathrm{~cm}^{3}$, then cut into fragments and processed for the different experimental procedures.

\section{Cell culture assays}

HC11 cells were maintained in growth medium (RPMI 1640 medium augmented with 10\% fetal bovine serum (FBS; Invitrogen, Carlsbad, CA, USA), $5 \mu \mathrm{g} / \mathrm{ml}$ insulin (Sigma, Saint Louis, MO, USA) and $2 \mathrm{mM}$ glutamine (Hyclone). MCF-7 and NMuMG cells were purchased from the American Type Culture Collection (Manassas, VA, USA), cultured as recommended and supplemented with 10\% FBS. SCp2 cells were grown in Dulbecco's modified Eagle's medium/F-12 (Invitrogen) supplemented with $2 \%$ FBS and $5 \mu \mathrm{g} / \mathrm{ml}$ insulin. LM3 and LMM3 were cultured in MEM (Hyclone), supplemented with 5\% FBS (Invitrogen). All cell lines were cultured with antibiotic-antimycotic (100 units/ml penicillin G sodium, $100 \mu \mathrm{g} /$ $\mathrm{ml}$ streptomycin sulfate, $250 \mathrm{ng} / \mathrm{ml}$ amphotericin B as Fungizone (Invitrogen)) at $37^{\circ} \mathrm{C}$ in a humidified atmosphere with $5 \%$ $\mathrm{CO}_{2}$ in air.

\section{Primary cultures}

MMTV(LA)-induced tumor primary cultures (TPCs) were prepared from HITs (that are, estrogen receptor-negative, progesterone receptor-negative (ER-PR-) neoplasias) (see Table 1). Tumor pieces were washed in MEM with antibiotic-antimycotic and passed through a nylon mesh. Sediment was resuspended in $20 \mathrm{ml}$ of MEM containing 1\% FBS and allowed to precipitate for 20 minutes. The liquid phase of the suspension was removed and cells were plated into $60 \mathrm{~mm}$ tissue culture dishes or six-well plates. Cells were cultured in MEM containing 1\% FBS and $10 \mathrm{ng} / \mathrm{ml}$ epidermal growth factor(Sigma Aldrich, Saint Louis, MO, USA); when the cells had grown to near confluence ( 3 to 4 days) they were rinsed with PBS and incubated in MEM containing 1\% FBS for 24 to 36 hours before experimental treatments. Culture dishes and plates were precoated by incubating them for 1 hour at room temperature $\left(18-22^{\circ} \mathrm{C}\right)$ with $50 \mu \mathrm{g} / \mathrm{ml}$ collagen in $0.02 \mathrm{M}$ acetic acid (rat tail collagen, type 1; Becton Dickinson Labware, Franklin Lakes, NJ). The remaining solution was carefully aspirated and then rinsed with PBS. For the preparation of conditioned 
Table 1

\begin{tabular}{lll}
\hline \multicolumn{1}{l}{ Tumors, primary cultures and cell lines used in the experiments in this paper } & References \\
\hline Source & Description & [24,25,31] \\
\hline $\begin{array}{l}\text { Tumors and primary cultures } \\
\text { HDTs }\end{array}$ & MMTV(LA)-induced HDTs growing in vivo & [24,25,31] \\
HITs & MMTV(LA)-induced HITs growing in vivo & \\
TPC & Primary cultures derived from HITs & \\
LM3 tumors & Poorly differentiated adenocarcinomas derived from LM3 cells implanted subcutaneously in \\
BALB/c mice & & [47] \\
LM3 & Cell line established from a spontaneous mammary tumor in BALB/c mouse & [47] \\
LMM3 & Cell line derived from a highly metastatic mammary tumor in BALB/c mouse & [50,51] \\
HC11 & Normal mouse mammary epithelial cell line & [52] \\
SCP2 & Normal mouse mammary epithelial cell line & ATTC - CRL-1636 ${ }^{\text {TM }}$ \\
NMuMG & Normal mouse mammary epithelial cell line & ATTC - HTB-22 ${ }^{\text {TM }}$ \\
MCF-7 & Human ER+ breast cancer cell line &
\end{tabular}

HDT, hormone-dependent tumor; HIT, hormone-independent tumor; TPC, tumor primary culture; MMTV, mouse mammary tumor virus; ER, estrogen receptor, ATCC ${ }^{\circledR}$, American Type Culture Collection Number.

medium $(\mathrm{CM})$, established primary cultures were grown in serum-free MEM for 15 hours and then in MEM containing 1\% FBS for 2 days before the supernatant was collected. CM was then mixed with fresh medium to final proportions of $30 \%$, $50 \%$ and $80 \%$.

\section{Biological and chemical reagents}

Recombinant murine LIF (Sigma Aldrich) concentration is indicated in each experiment. Recombinant murine IL-6 (Sigma Aldrich) was used at $80 \mathrm{ng} / \mathrm{ml}$. For neutralization of LIF, $1 \mathrm{ml}$ of $C M$ was incubated with $0.8 \mu \mathrm{g}$ of anti-mLIF neutralizing antibody (R\&D Systems, Minneapolis, MN, USA) at room temperature for 1 hour before cell treatment [27]. To inhibit extracellular signal-regulated kinase (ERK) $1 / 2$ activbation serum-starved $\mathrm{HC} 11$ cells were pretreated for 1 hour with 30 $\mu \mathrm{M}$ PD98059 (Calbiochem, San Diego California) or with vehicle ( $1 \% \mathrm{v} / \mathrm{v}$ dimethyl sulfoxide) and then treated with LIF for 5 minutes (for Western blot analysis) or 72 hours (for cell viability assays). Treatment with Src inhibitor (PP2; Calbiochem) was performed as described previously [28]. In brief, $\mathrm{HC} 11$ were starved for 1 hour and preincubated with $30 \mu \mathrm{M}$ PP2 for 15 minutes before treatment with LIF for 5 minutes. In order to inhibit Stat3 activation, cell cultures were pretreated with $1 \mathrm{mM}$ Stat3-specific inhibitory peptide (Stat3ip; Calbiochem) 1 hour before stimulation with LIF for the indicated periods.

\section{Morphological and immunohistochemical studies}

Tumors and normal mammary glands were fixed in 10\% buffered formalin and embedded in paraffin by using standard pro- cedures [17]. In brief, after paraffin sections had been dewaxed, they were rehydrated and either stained with hematoxylin and eosin or used for immunohistochemical studies. LIF immunohistochemistry was performed as described [17] with a polyclonal mouse LIF antibody (SC-1336). Stat3 immunohistochemistry was conducted with a polyclonal rabbit anti-Stat3 antibody (SC-482) (Santa Cruz Biotechnology, Inc., Santa Cruz, CA, USA). Detections were performed with the Vectostain Elite $A B C$ immunoperoxidase system (Vector Laboratories, Burlingame, CA, USA) in accordance with the manufacturer's instructions with diaminobenzidine (Dako, Carpinteria, CA, USA) as chromogen. LIF and Stat3 immunostaining were qualitatively evaluated by: (1) the presence or absence of staining; (2) the type of structure with positive staining and (3) the pattern and/or cellular localization of staining. Negative controls were performed by replacing the primary antibody with normal rabbit serum.

\section{Immunofluorescence}

HC11 were cultured on Lab-tek chamber slides (NUNC, Rochester, NY, USA) for 48 hours, then preincubated with Stat3 inhibitor peptide for 1 hour and treated with LIF (50 ng/ $\mathrm{ml}$ ) for 30 minutes. After that, cells were fixed in 4\% paraformaldehyde for 25 minutes at room temperature, washed with PBS and preincubated at room temperature for 5 minutes with PBS-based blocking buffer containing 0.1\% SDS and 3\% bovine serum albumin. After being rinsed with PBS, the cells were incubated with a 1:100 dilution of rabbit polyclonal antiStat3 antibody (SC-482, Santa Cruz Biotechnology) in the same blocking buffer. After being washed with PBS, cells 
were incubated for 1 hour with a 1:500 dilution of Cy3-conjugated affiniPure donkey anti-rabbit $\mathrm{lgG}(1.5 \mathrm{mg} / \mathrm{ml}$; Jackson Immunoresearch Laboratories, West Grove, PA, USA).

Cells were mounted and observed under an Olympus Fluoview FV300 Confocal Laser Scanning Biological Microscope. Images were analyzed by using Adobe Photoshop (Adobe Systems, Inc., New York, NY, USA).

\section{Protein extraction}

Total proteins were extracted from frozen mammary glands, frozen tumor tissue or cell lines in RIPA protein extraction buffer (50 mM Tris- $\mathrm{HCl} \mathrm{pH} 7.4,150 \mathrm{mM} \mathrm{NaCl}, 1 \%$ Triton X$100,0.25 \%$ sodium deoxycholate, $1 \mathrm{mM}$ EDTA) supplemented with protease (protease inhibitor cocktail set I; Calbiochem) and phosphatase inhibitors $(1 \mathrm{mM} \mathrm{NaF}$ and $1 \mathrm{mM}$ $\left.\mathrm{Na}_{2} \mathrm{VO}_{4}\right)$. Samples were homogenized and further disrupted by passage through a 21 -gauge needle ( 8 to 10 times). They were subsequently incubated on ice for 30 minutes and centrifuged at $9,500 \mathrm{~g}$ for 20 minutes at $4^{\circ} \mathrm{C}$. Supernatants were transferred to a fresh tube and the protein concentration was determined by the Bradford method [29]. Cleared lysates were combined with SDS sample buffer $(50 \mathrm{mM}$ Tris-HCl pH $6.8,2 \%$ SDS, $0.1 \%$ bromophenol blue, $10 \%$ glycerol, 100 $\mathrm{mM}$ dithiothreitol), boiled for 8 minutes and resolved by SDSPAGE.

\section{Immunoprecipitation}

Protein extracts $(1.5 \mathrm{mg})$ from mouse tumors were incubated with $7 \mu \mathrm{l}$ of anti-Stat3 (C-20; Santa Cruz Biotechnology) at $4^{\circ} \mathrm{C}$ overnight, with horizontal rotation. Protein A/G-Sepharose beads (Santa Cruz Biotechnology) were added and incubation continued for a further 2 hours at room temperature. Samples were then washed three times with PBS and resuspended in $10 \mu$ lof the previously described sample buffer.

\section{Western blot analysis}

Proteins were run on $10 \%$ SDS-polyacrylamide gels $(80 \mu \mathrm{g}$ per lane), blotted to poly(vinylidene difluoride) membranes (Bio-Rad) and incubated with blocking solution (5\% dry skimmed milk dissolved in TBS-T, $50 \mathrm{mM}$ Tris- $\mathrm{HCl} \mathrm{pH}: 8.8$, $150 \mathrm{mM} \mathrm{NaCl}$ and $0.1 \%$ Tween) for 1 hour. A set of prestained molecular mass standards was run in each gel. Membranes were incubated overnight at $4^{\circ} \mathrm{C}$ with the appropriate dilution of the following primary antibodies: a rabbit polyclonal antiStat3 antibody (C-20, SC-482), a mouse monoclonal antityrosine-phosphorylated (pY) Stat3 (SC-8059), a rabbit polyclonal anti-ERK (SC-154) and a mouse monoclonal anti-pYERK (SC-7383). All antibodies were purchased from Santa Cruz Biotechnology. Membranes were washed with TBS-T before incubation with horseradish peroxidase-conjugated anti-mouse or anti-rabbit secondary antibodies (Santa Cruz Biotechnology). Immunoreactive protein bands were detected by enhanced chemiluminescence (ECL+Plus System; Amersham Biosciences).

\section{RNA analysis}

Mammary gland and mammary tumor RNA was obtained using the SV Total RNA Isolation System (Promega, Madison, WI, USA) in accordance with the manufacturer's instructions. RNA from cell lines and primary cultures was obtained with Trizol (Invitrogen). For Northern blot analysis, poly(A) RNA was obtained and processed as described previously [17]. For RTPCR analysis, cDNA was generated from $2 \mu \mathrm{g}$ of total RNA using Moloney murine leukemia virus reverse transcriptase (Promega), $10 \mu \mathrm{l}$ of reverse transcription buffer, oligodeoxythymidylic acid primer, $25 \mathrm{mM}$ deoxynucleoside triphosphates mix and RNase inhibitor (Promega) in a final reaction volume of $20 \mu \mathrm{l}\left(60\right.$ minutes at $40^{\circ} \mathrm{C}$ followed by 5 minutes at $90^{\circ} \mathrm{C}$ ). The primers and amplification protocol used in detecting LIF, LIF-R and actin expression have been reported previously [17]. For gp130, the sense and antisense primers used were 5'-TCGGAGGAGCGGCCAGAAGAC-3' and 5'ATCAGCCCCCGTGCCAAGAGC-3', respectively. For CCAAT-enhancer-binding protein $(\mathrm{C} / \mathrm{EBP}) \delta$, the sense and antisense primers used were 5'-ACCCGCGGCCTTCTACGA-3' and 5'-CGCCCCTTTTCTCGGACTGT-3', respectively. Products were subjected to electrophoresis in $2 \%$ agarose gels. For detection of LIF-M and LIF-D expression, the sense primer sequence for LIF-M was 5'-TGGAAAGCTGTGATTGGCGCGAGA-3' and that for LIF-D was 5'TGGAGTCCAGCCCATAATGAAGGT-3' ; in both cases a primer from exon 3 was used (5'-TGGAGTCCAGCCCATAATGAAGGT-3') and the PCR was performed with 35 amplification cycles. The products were subjected to electrophoresis on $2 \%$ agarose gel.

Real-time PCR data were acquired and analyzed with an Opticon Monitor System (MJ Research, Bio-RAD, Hercules CA, USA) and each amplification mixture was performed in $3.5 \mathrm{mM}$ $\mathrm{MgCl}_{2}, 4 \mu \mathrm{M}$ forward primer, $4 \mu \mathrm{M}$ reverse primer, 1:30,000 SYBR Green (Invitrogen) with the previously described RTPCR kit and protocols [17] but using 35 amplification cycles. All samples were analyzed for actin expression in parallel in the same run. For each sample, the amplification plot and the corresponding dissociation curves were examined. The specificity of the amplified product was monitored by examining the melting curve and the melting peak of the product. The absence of nonspecific amplification was confirmed for each gene by analyzing the PCR amplification products by agarose gel electrophoresis. To estimate mRNA expression, calibration curves were made. Experiments were always run in duplicate and repeated at least twice.

\section{Cell viability assays}

Cell viability was evaluated by staining with crystal violet as described previously [30]. In brief, cells were treated as indicated and fixed with $1.1 \%$ glutaraldehyde at the end of each experiment. After being washed with deionized water and dried in air, plates were stained with a $0.1 \%$ crystal violet solution. The bound dye was solubilized with $10 \%$ acetic acid and 
Figure 1

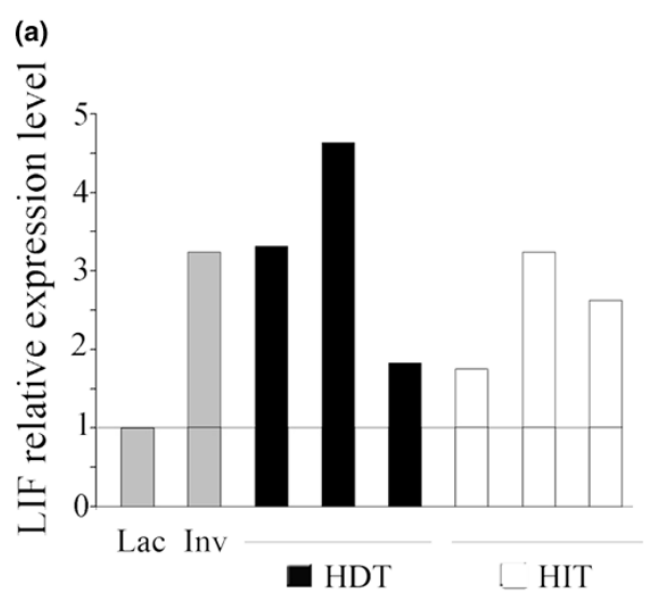

(b)

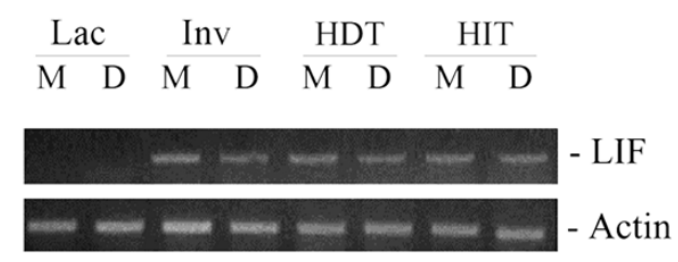

(c)
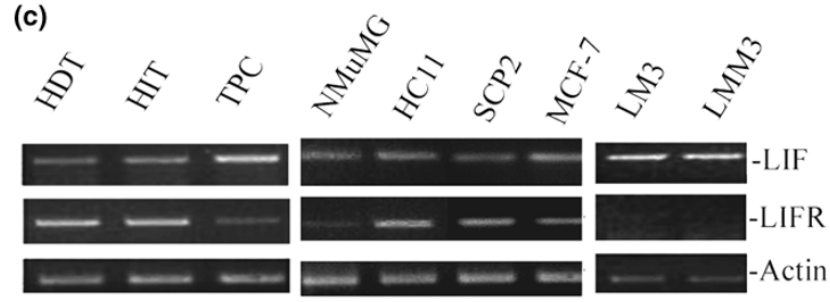

Expression of LIF and LIF receptor mRNA in mammary tumor cells. (a) Real-time PCR showing relative expression levels of leukemia inhibitory factor (LIF) in hormone-dependent (HDT) and hormone-independent (HIT) mouse mammary tumors compared with lactating (Lac) and 48hour involuting (Inv) normal mammary glands. All samples were analyzed and normalized to actin expression in parallel in the same realtime PCR assay. (b) Ethidium bromide stained gel showing RT-PCR analysis of two different LIF splicing variants: LIF-M and LIF-D. (c) Ethidium bromide stained gel showing LIF and LIF-R expression by RTPCR in HDT, HIT and in culture growing mammary cell lines: NMuMG, HC11, SCp2 (epithelial non-tumorigenic), MCF-7, LM3, LMM3 (tumorigenic mammary cell lines) and mammary tumor primary cultures (TPC).

quantified at $590 \mathrm{~nm}$ in a Benchmark microplates reader (BioRad Laboratories, Hercules, CA, USA).

\section{Results \\ Expression of leukemia inhibitory factor (LIF) and LIF receptor in mouse mammary tumor cells}

First, LIF expression was analyzed in MMTV(LA) induced HDTs and HITs (see Table 1) $[24,25,31]$. When the LIF mRNA content from different HDTs $(n=3)$ and HITs $(n=3)$ was com- pared with lactating and involuting normal mammary glands, we found (by quantitative RT-PCR) that this cytokine was expressed in all these tumors, although its level varied between them independently of its dependence on hormone (Fig. 1a). These results were confirmed by Northern blot analysis (data not shown). Because it has been demonstrated that there are two alternatively spliced LIF transcripts that originate two differentially localized LIF proteins, a secreted 'free' form (LIF-D) and an extracellular matrix-associated one (LIF-M) [32], their presence was analyzed by RT-PCR with specific sets of primers. Our results show that both the LIF-D and LIF-M transcripts are present in mammary tumors and involuting glands (Fig. 1b). To determine the relevance of autocrine LIF in mammary cells, the expression of LIF and LIF-R was determined by RT-PCR in HDTs, HITs, their primary cultures, and mouse (non-tumorigenic and tumorigenic) and human (tumorigenic) mammary cell lines (NmuMG, HC11, SCp2, LM3, LMM3 and MCF-7; Table 1). We found that all those cells express LIF, although tumor cells tend to show higher levels than non-tumorigenic ones. Interestingly, LIF-R was also present in all cell lines tested, with the exception of LM3 and LMM3 (Fig. 1c).

\section{LIF expression and Stat3 localization analysis; histological studies}

Morphologically, MMTV(LA)-induced tumors are classical adenocarcinomas with various grades of differentiation. Figure $2 \mathrm{a}$ shows an example of a moderately differentiated HIT with many cystic papillary areas. Although these tumors also show poorly differentiated solid regions, round epithelial cells forming small glandular structures could be observed in these areas (Fig. 2a, inset). In contrast, LM3 tumors are poorly differentiated adenocarcinomas with large tumor cells and hyperchromatic nuclei. They also show an abundant vascular stroma that contains many fibroblasts, neutrophils, lymphocytes, plasma cells, and occasionally mast cells (Fig. 2b). Apoptotic images and extensive hemorrhagic necrosis are also seen. In addition, because of the fusiform feature and swirled disposition of some cells, there are areas with a sarcomatous appearance (Fig. 2b, inset).

LIF expression has been tested by immunohistochemistry in HITs and in LM3 tumors (Table 1). In both cases, LIF staining was predominantly epithelial, although some positive stromal cells could be seen (Fig. 2c, d). The expression of LIF in involuting and lactating mammary glands is shown as a positive and a negative control, respectively (Fig. $2 \mathrm{e}, \mathrm{f}$ ).

To determine the level of Stat3 activation in HITs and LM3 tumors, its intracellular localization has been determined by immunohistochemical analysis. Whereas in HITs the images show positive staining in epithelial and stromal nuclei (Fig. $2 \mathrm{~g}$ ); in LM3 tumors Stat3 staining was detected mostly in the cytoplasm of epithelial cells (Fig. 2h), which indicates a lack of Stat3 activation in these tumors. This observation was confirmed by Western blot analysis: all the analyzed HITs showed 

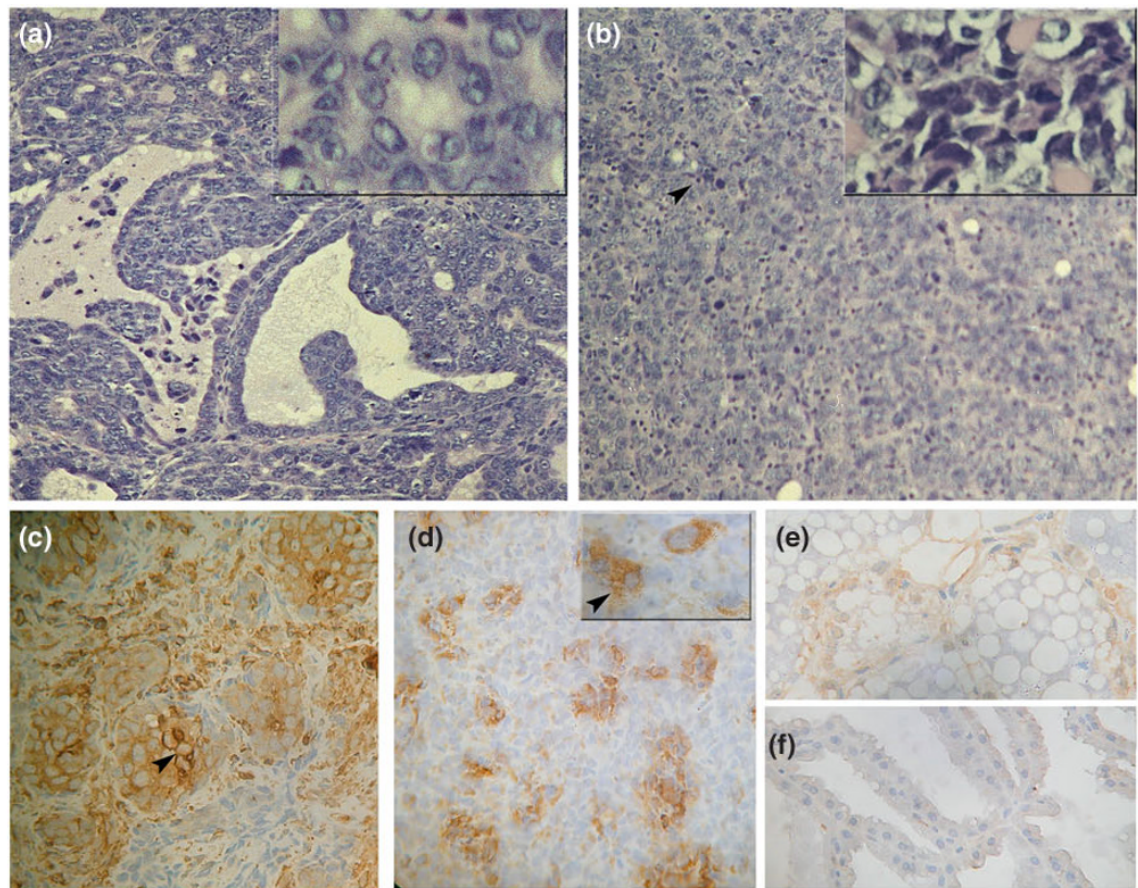

(f)
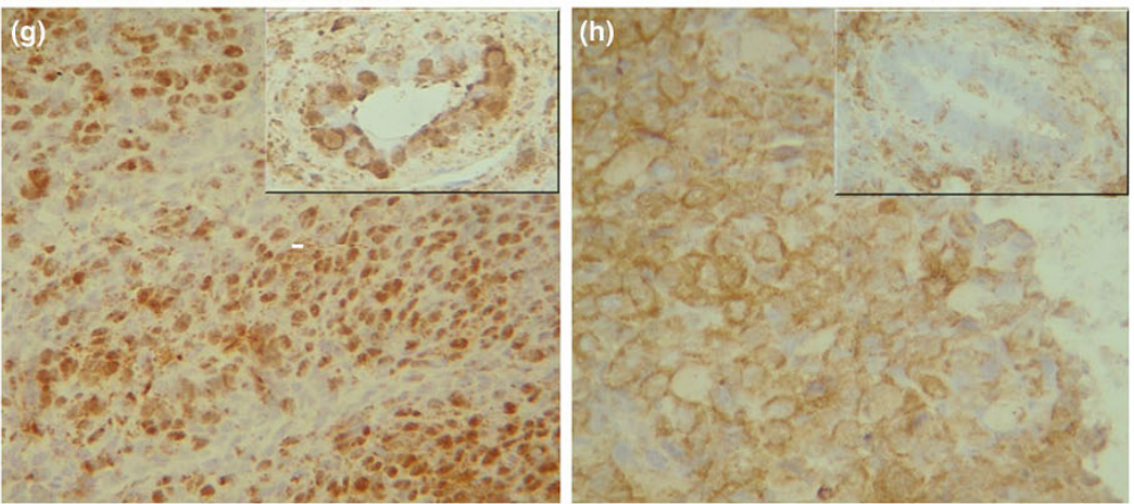

Morphological and immunohistochemical analysis of MMTV(LA)-induced HIT and LM3 mammary tumors growing in vivo. (a, b) Hematoxylin/eosinstained tumors. (a) Moderately differentiated hormone-independent tumors (HIT). Papillary formations into lumen of cystic ducts and less differentiated zones with small glandular structures. Original magnification $\times 100$; inset $\times 400$. (b) LM3 poorly differentiated adenocarcinoma with abundant infiltrated vascular stroma. Areas with sarcomatous appearance and apoptotic images (black arrowheads). Original magnification in (a, b) $\times 100$; inset $\times 400$. (c-f) Leukemia inhibitory factor (LIF) immunohistochemistry. (c) HIT: heterogenous and regular distribution mainly in poorly differentiated areas with cytoplasmic and nucleic positive staining; intense cytoplasmic staining increasing peripherally indicates a secretory pattern (arrowhead). (d) LM3 tumor: patchy LIF staining. Inset: positive cytoplasmic staining; the ill-defined cell membrane pattern with granular cytoplasmic staining indicates LIF secretion (arrowhead). (e) Involuting (48-hour) and (f) lactating mammary glands were used as positive and negative controls, respectively, for LIF staining. Original magnification in (c-f) $250 \times$; inset: $400 \times(\mathbf{g}, \mathbf{h})$ Stat3 (signal transduction and activators of transcription 3 ) immunohistochemistry. (g) HIT: stromal and predominantly epithelial positive nuclear staining in solid areas. Inset: stained nuclei were also seen in glandular regions. (h) LM3 tumor: intense cytoplasmic positive staining in stromal and epithelial cells. The inset shows a negative gland surrounded by positive stromal cells. Original magnification in (g, h) 250x; inset: 400x

much higher levels of pY-Stat3 than LM3 tumors (Fig. 3a). These results suggest that the lack of LIF-R expression results in a much lower activation of Stat3 in the LM3 tumors.

\section{Tyrosine phosphorylation of Stat3 in culture}

For further analysis of the hypothesis that LIF-mediated signaling would be a determinant for Stat3 activation in mouse mammary tumors, the capacity of LIF to induce tyrosine phosphorylation of Stat3 was analyzed in cultured cells. Our results show that LIF was able to induce transient Stat3 activation in $\mathrm{HC} 11$ and TPC cells, achieving the highest level of tyrosine phosphorylation after 15 minutes. However, no pYStat3 was observed in LIF-treated LM3 cells (Fig. 3b, c).

To determine the integrity of the gp130/JAK/Stat3 signaling pathway in LM3 cells, gp130 expression and the capacity of 
Figure 3

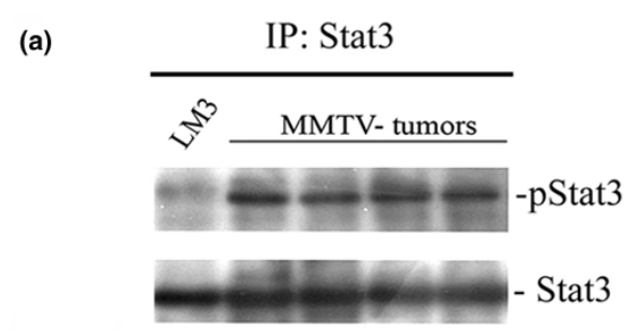

(b)

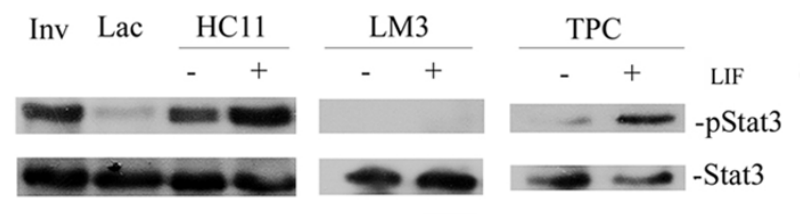

(c)

\begin{tabular}{|c|c|c|c|c|c|c|c|}
\hline \multicolumn{7}{|c|}{ HC11 + LIF } & \multirow[b]{2}{*}{ Time } \\
\hline 0 & $15^{\prime}$ & $30^{\prime}$ & $1 \mathrm{~h}$ & $2 \mathrm{~h}$ & $4 \mathrm{~h}$ & $8 \mathrm{~h}$ & \\
\hline 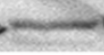 & & & $=$ & Lanes & $=$ & - & -pStat \\
\hline - & 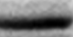 & 20 & dene & inge & $=$ & 10 & -Stat3 \\
\hline
\end{tabular}

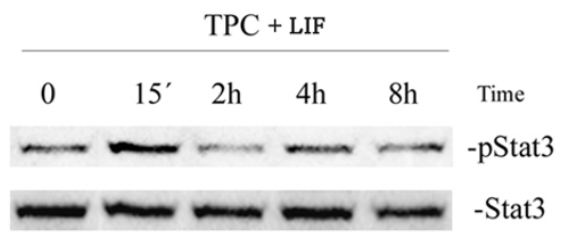

(d)

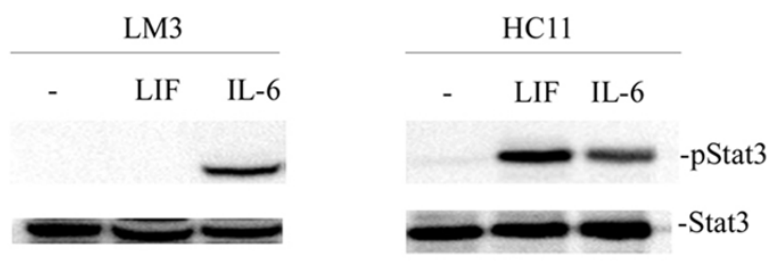

Western blot analysis of phospho-Stat3 (pStat3) and Stat3. (a) Tumors growing in vivo: LM3 (lane 1) and different HIT transplants (lanes 2 to 5). (b-d) Cells growing in culture. (b) $\mathrm{HC} 11, \mathrm{LM} 3$ and tumor primary culture (TPC) cells treated with $80 \mathrm{ng} / \mathrm{ml}$ leukemia inhibitory factor (LIF) for 15 minutes; mammary glands at 48 hours of involution (Inv) and at fifth day of lactation (Lac) were used as positive and negative controls, respectively. (c) Time course of tyrosine phosphorylation of Stat3 (signal transduction and activators of transcription 3 ) in $\mathrm{HC} 11$ cells (upper panel) and TPC cells (lower panel) treated with $80 \mathrm{ng} / \mathrm{ml}$ LIF. (d) Tyrosine phosphorylation of Stat3 in $\mathrm{HC} 11$ and LM3 cells treated with LIF and IL-6 (both at $80 \mathrm{ng} / \mathrm{ml}$ ) for 15 minutes. another LIF-family cytokine to induce Stat3 phosphorylation was evaluated. We found similar levels of gp130 mRNA in all cells tested (HC11, TPC and LM3; data not shown). In addition, IL-6-treated LM3 cells showed a significant level of $p Y-$ Stat3 (Fig. 3d). This suggests that the lack of Stat3 activation in LIF-treated LM3 cells was due to a deficiency in LIF-R expression and not to the impairment of another component of the gp130/JAK/Stat3 signaling cascade.

We next investigated the capacity of TPC CM to induce Stat3 phosphorylation in mammary cells. Our results show that $\mathrm{CM}$ induced Stat3 phosphorylation in $\mathrm{HC}_{11}$ cells (Fig. 4a, upper panel). Interestingly, this treatment was unable to induce Stat3 activation in LM3 cells (Fig. 4a, lower panel). A LIF blocking antibody was then used to determine whether this cytokine was responsible for the CM-induced Stat3 activation. Our results show a clear inhibition of this activity in $\mathrm{HC} 11$ and TPC cells (Fig. 4b). Notably, this antibody was unable to completely block the capacity of LIF ( 3 to $5 \mathrm{ng} / \mathrm{ml}$ ) to induce Stat3 phosphorylation in $\mathrm{HC} 11$ cells (Fig. 4c). The remaining Stat3 activation observed in cells treated with $\mathrm{CM}$ plus LIF-blocking antibody could therefore still have been due to residual LIF activity in the presence of this antibody. These results indicate that locally produced LIF exerts a major role on Stat3 tyrosine phosphorylation in mammary tumors.

To determine whether Stat3 tyrosine phosphorylation induced by $\mathrm{CM}$ resulted in transcriptional activation of this factor, we assessed the expression of a known transcriptional target of Stat3, namely C/EBPS [33]. Our results show that LIF as well as $\mathrm{CM}$ induces $\mathrm{C} / \mathrm{EBP} \delta$ transcription in mammary tumor cells and that $\mathrm{CM}$-dependent $\mathrm{C} / \mathrm{EBP} \delta$ induction was inhibited by pretreatment with LIF-blocking antibody (Fig. 4d).

It has been reported that the IL-6 cytokine family is able to induce Stat3 activation through the gp130 receptor by using an 'unconventional' signaling route that involves ERK $1 / 2$ phosphorylation [34]. The ability of LIF to induce this mitogen-activated protein kinase (MAPK) activation was then evaluated in HC11 cells. LIF $(5 \mathrm{ng} / \mathrm{ml})$ induced a detectable activation of ERK1/2 that disappeared in the presence of LIF-blocking antibody (Fig. 4c). However, the use of a MAPK/ERK kinase (MEK)-specific inhibitor (PD98059) completely blocked LIFinduced ERK1/2 activation but did not affect the induction of Stat3 tyrosine phosphorylation (Fig. 4e). These results indicate that the ERK $1 / 2$ activation achieved with 5 to $20 \mathrm{ng} / \mathrm{ml}$ LIF does not exert a major effect on Stat3 activation in $\mathrm{HC} 11$ cells. In addition, PP2, a selective inhibitor of Src family of protein tyrosine kinases, had no effect on LIF-induced Stat3 tyrosine phosphorylation in mammary cells (Fig. 4f), suggesting that this effect would not depend on Src activation. 
(a)

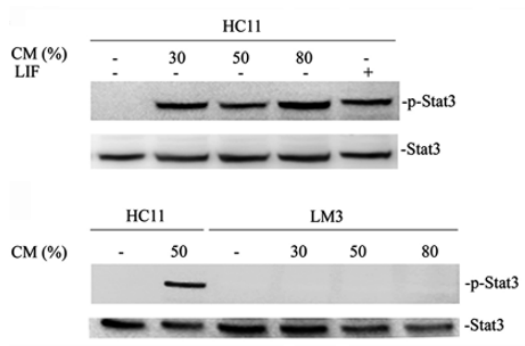

(b)

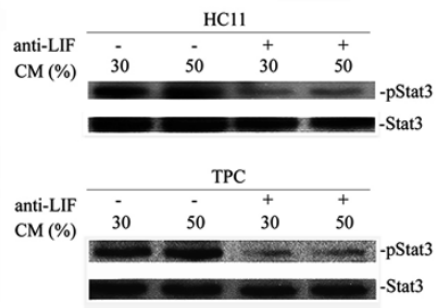

(c)

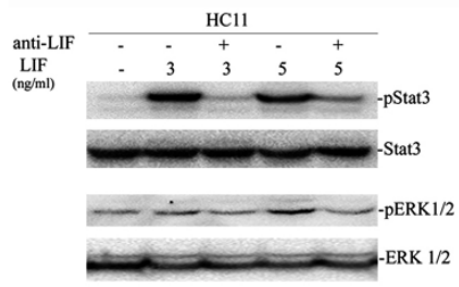

(d)

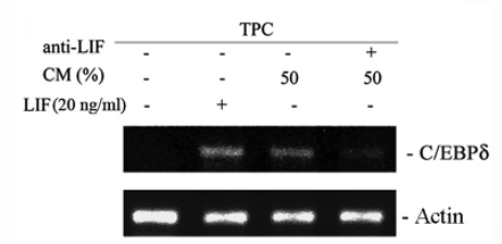

(e)

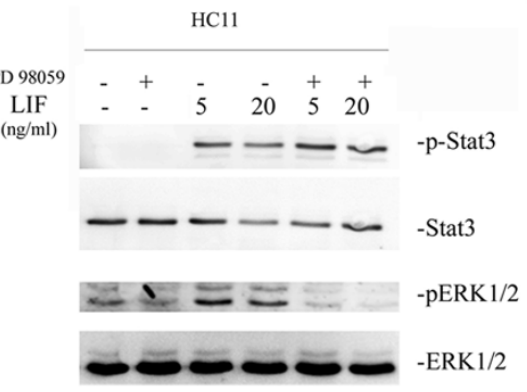

(f)

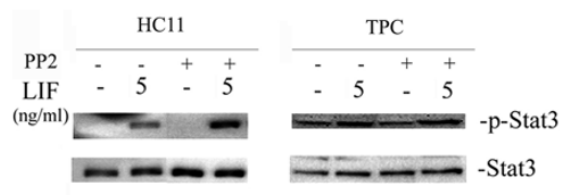

Effect of tumor primary culture (TPC) conditioned medium (CM) and leukemia inhibitory factor (LIF)-neutralizing antibody. (a) Stat3 (signal transduction and activators of transcription 3) and phospho-Stat3 (p-Stat3) in HC11 and LM3 cells treated with increasing concentrations of CM (30\%, $50 \%$ and 80\%). (b) Stat3 and p-Stat3 levels in HC11 and TPC cells treated with CM that had been preincubated with or without LIF-neutralizing antibody. (c) Phosphorylation levels of Stat3 and extracellular signal-regulated kinase (ERK) $1 / 2$ in HC11 cells treated with LIF ( 3 and $5 \mathrm{ng} / \mathrm{ml}$ ) preincubated with or without LIF-neutralizing antibody. (d) Expression of CCAAT-enhancer-binding protein (C/EBP) $\delta$ in TPC cells treated with CM with or without neutralizing antibody. (e) Phosphorylation of Stat3 and ERK1/2 in HC11 cells treated with LIF with or without the MAP kinase/ERK kinase inhibitor PD98059. (f) p-Stat3 and Stat3 in HC11 and TPC cells treated with LIF with or without the Src-specific inhibitor PP2. Experiments were repeated at least three times with similar results. No effect was observed on phosphorylation levels of either Stat3 or ERK1/2 when HC11 cells were treated with the PD98059 vehicle, dimethyl sulfoxide (data not shown).

To analyze the biological activity of LIF on mouse mammary tumor and non-tumor cells, we evaluated the effect of this cytokine on the survival of HC11, TPC and LM3 cells. We have found that 72 hours of LIF treatment induced a dosedependent inhibition of $\mathrm{HC} 11$ cell survival, whereas it also caused a dose-dependent increase in the number of viable primary tumor cells. As expected, no effect was observed in LIFtreated LM3 cells (Fig. 5a). Similarly, CM induced opposite effects on the viability of $\mathrm{HC} 11$ and TPC cells; these were prevented by pretreatment with a LIF-blocking antibody (Fig. 5b).

Then, to determine whether Stat3 and/or ERK1/2 activation were involved in the effect of LIF on cell survival, $\mathrm{HC} 11$ and TPC cells were treated with this cytokine for 72 hours in the presence or absence of Stat3ip or PD98059. As expected, the inhibitory effect of LIF on the survival of HC11 cells was blocked by Stat3ip. Interestingly, this treatment did not inhibit the stimulatory activity of LIF on TPC cell survival; instead, it significantly enhanced it (Fig. 5c). In contrast, blocking ERK1/ 2 activation had a marked inhibitory effect on TPC cell survival, whereas the same assay produced a much milder response in HC11 cells (Fig. 5f). As has previously been reported by others, we confirmed the inhibitory capacity of Stat3ip ( $1 \mathrm{mM})$ by analyzing its ability to interfere with LIF-induced Stat3 phosphorylation (Fig. 5d) [35] and nuclear translocation (Fig. 5e) [36]. Therefore, the different biological activity displayed by LIF on normal cells and tumor cells might be due to the altered biological response that tumor cells develop to the activation of certain signaling pathways rather than to a differential effect of this cytokine on its intracellular mediators. 
(a)

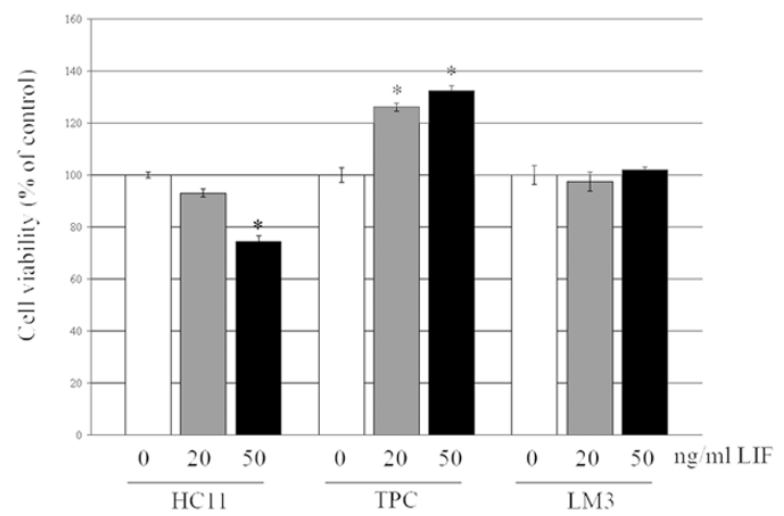

(b)

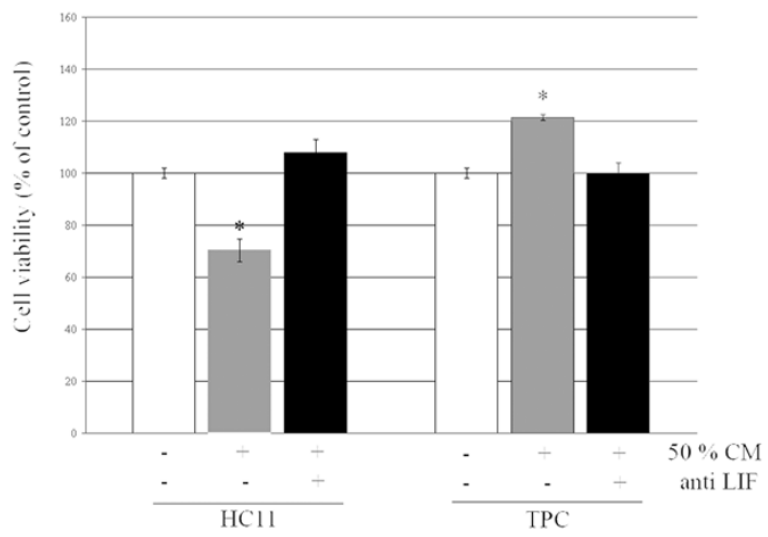

(c)

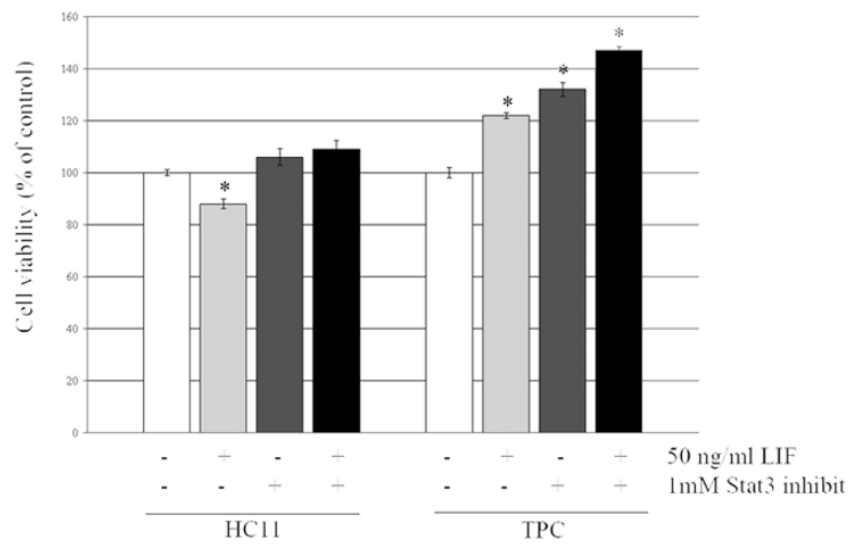

(d)

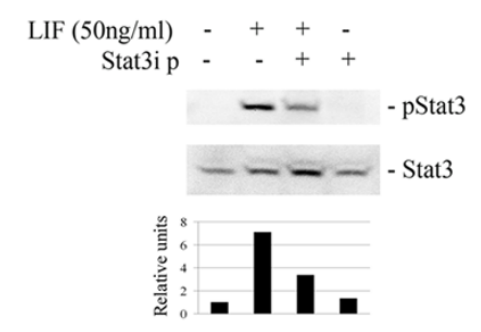

(e)

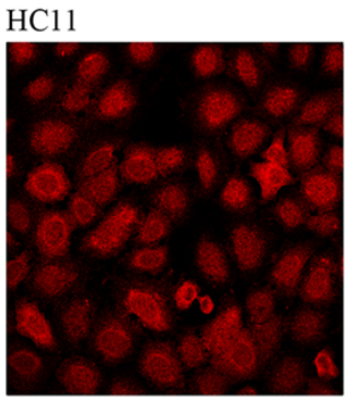

HC11+ Stat3ip
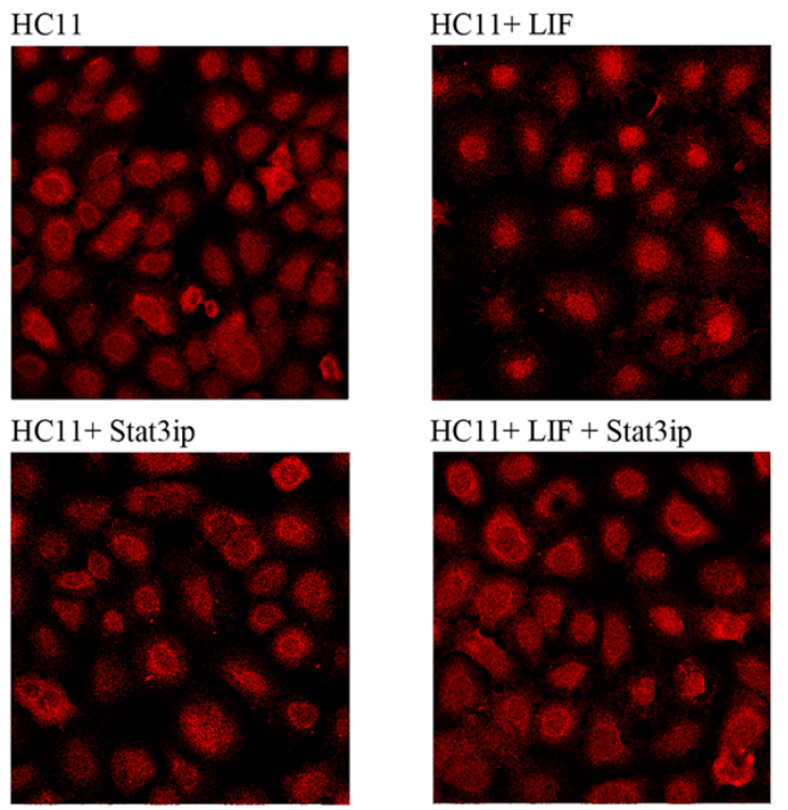

HC11+ LIF + Stat3ip

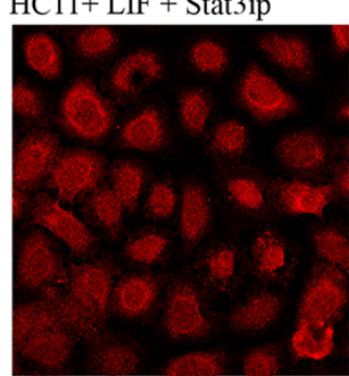

(f)

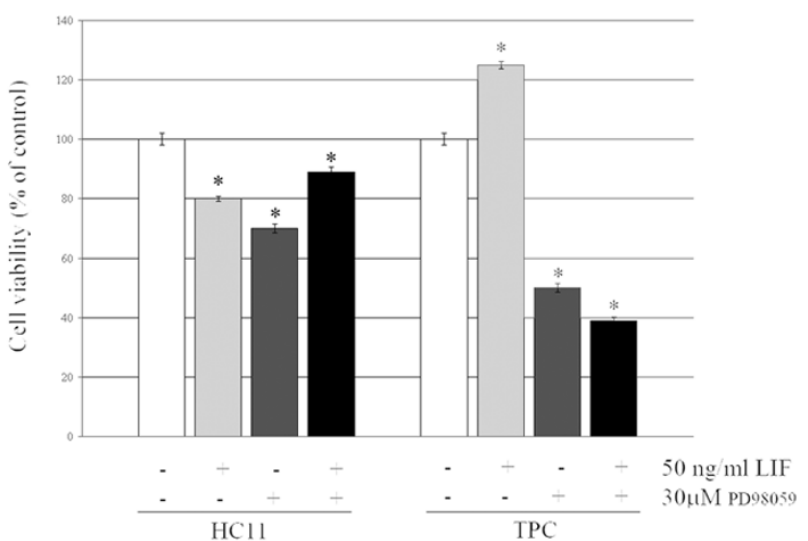

Effect of LIF and CM on cell viability after 72 hours of treatment. Viability was assessed by crystal violet assays. (a) HC11, tumor primary culture (TPC) and LM3 cells were treated with leukemia inhibitory factor (LIF; 20 and $50 \mathrm{ng} / \mathrm{ml}$ ). (b) HC11 and TPC cells were treated with $50 \%$ conditioned medium (CM) preincubated with or without LIF-neutralizing antibody. (c) HC11 and TPC cells were treated with $50 \mathrm{ng} / \mathrm{ml}$ LIF in the presence or absence of a Stat3 (signal transduction and activators of transcription 3) inhibitor peptide. (d, e) Effect of Stat3-specific inhibitory peptide (Stat3ip) on Stat3 phosphorylation levels (d) and nuclear translocation (e) induced by LIF. 400× (f) HC11 and TPC cells were treated with $50 \mathrm{ng} / \mathrm{ml}$ $\mathrm{LIF}$ in the presence or absence of PD98059. Data are percentages of internal control for each cell type (time 0 ) and are expressed as means \pm SEM for four replicates. Experiments were repeated at least three times with similar results. Asterisk denotes statistical difference $(P<0.05)$ in a twotailed Student's $t$ test. 


\section{Discussion}

Activation of Stat3 has been detected in many human neoplasias [37,38], and it has been shown that IL-6-type cytokines induce Stat3 phosphorylation in various human and rodent cell lines [21,23]. In addition, it has been demonstrated that these cytokines, including LIF, are expressed in breast cancer cells and in other tumor types $[4,39]$. Interestingly, in certain myeloma and prostate cancer cell lines, IL- 6 has been identified as the main cytokine responsible for Stat3 activation induction $[40,41]$. In addition, a very recent report suggests a similar role for this cytokine in breast cancer cells [42]. In mouse mammary glands during post-lactational involution, both induction of IL- 6 and LIF expression and Stat3 activation have been demonstrated $[17,18,34]$. Interestingly, in this context, Stat3 activation seems to be more dependent on LIF than on IL-6 status [43]. In mammary tumors, to our knowledge, no report has yet been made linking LIF expression to Stat3 activation.

It has been reported that LIF and LIF-R expression in breast tumors is associated with favorable biological features such as diploidy and low S-phase fraction. In addition, in those tumors LIF-R expression was correlated with the presence of ER [3]. On the basis of these data, those authors postulated that tumors expressing LIF/LIF-R would represent a phenotype that is closer to 'normal' and would therefore be less aggressive. Interestingly, although it has been shown that Stat3 expression and activation is commonly found in breast cancer cells [15], and this transcription factor activation resulted in the malignant transformation of fibroblasts [43] and the proliferation of mammary tumor cells $[4,6,44,45]$, there is also evidence that Stat3 activation in human breast cancer is associated with a better prognosis [46].

Our results in mouse mammary tumors also show an association between LIF-R expression and Stat3 activation with a less aggressive phenotype. LIF- ${ }^{+}$MMTV(LA)-induced tumors appear in mid-pregnancy, when serum progesterone and estrogen levels are high, and continue to grow until delivery. After this, they soon regress and reappear in subsequent gestations, suggesting that progesterone and/or estrogen have a main role in their development. In addition, these tumors show high expression of estrogen and progesterone receptors $\left(E R^{+} P R^{+}\right)$. Eventually, in the same mouse or after successive passages, these neoplasias progress to become autonomous: they lose hormone receptor expression and grow independently of the female's hormonal status [24]. However, in spite of this drastic change in hormone dependence, MMTV(LA) HITs are not very aggressive and show a variety of histological patterns, from well-differentiated to very poorly differentiated architecture [24]. They also remain LIF responsive and show Stat3 activation. In contrast, the LM3 cell line, which derives from a spontaneous BALB/c mammary adenocarcinoma, gives rise to ER- PR- poorly differentiated highly invasive (100\% incidence of lung metastasis) tumors [47]. Here we have shown that these tumors do not express LIF-R and show low levels of Stat3 activation. Our results from mouse mammary tumors are therefore in good agreement with data from human breast cancer samples. This suggests that, in certain cases, these experimental models can be better tools than breast cancer cell lines for reproducing particular aspects of human malignancies.

In transformed cells, there are no known naturally occurring mutations in Stat3 that lead to its constitutive activation. Alternatively, it has been proposed that Stat3 activation in tumors and in oncogene-transformed cells would be dependent on growth factor tyrosine kinase receptor activation or deregulation of JAK kinase's activity [48]. The results shown here demonstrate that in well-differentiated mouse mammary tumors the constitutive activation of Stat3 would be mostly dependent on overexpression of LIF. The phosphorylation regulatory pathways of this transcription factor might therefore not be altered in these cancer cells. In addition, it has been shown that blocking ERK1/2 phosphorylation resulted in inhibition of Stat3 activation in Jak2-null cells, whereas no effect on pY-Stat3 has been observed in wild-type cells [43]. Similarly, in HC11 cells we have not found a clear effect on Stat3 tyrosine phosphorylation when ERK1/2 activation was blocked. These results suggest that this MAPK could have a relevant role in mammary Stat3 activation only when the gp130/Jak2 pathway has been impaired in some way.

Our results from the crystal violet assays indicate that treatment with LIF can produce different biological responses in non-tumorigenic and tumorigenic cells, namely inhibiting and inducing cell survival, respectively. However, and in spite of this cytokine's being the principal one responsible for Stat3 phosphorylation, in both cases blocking Stat3 activation increased cell survival. It has been shown that expression of the phosphoinositide 3-kinase regulatory subunits p55 $\alpha$ and p50 $\alpha$ is directly induced by Stat3 during mammary gland involution [18]. These proteins are involved in the downregulation of phosphoinositide 3-kinase signalling and Akt/protein kinase $B$ activity, and abrogation of this survival pathway is essential for the induction of apoptosis in mammary epithelial cells [18]. Our interpretation for the results shown here is therefore that in certain mammary tumor cells this apoptosis-inducing pathway is still functioning. However, these cancer cells are not fully responsive to the strategies for controlling cell survival because they are very sensitive to the activation of proliferative signaling pathways. For example, our results show clearly how much more susceptible tumor cells are to inhibition of MEK activity. We therefore believe that in both normal and neoplastic mammary cells LIF is able to induce both the survival and apoptotic pathways, the balance of which can lead to completely different outcomes in these cell types.

Stat3 biological activity depends on multiple factors, many still unknown. For example, in melanoma cells, IL-6/Stat3 function is modulated by the stage of tumor progression [49]. The 
results shown here suggest that in well-to-moderately differentiated mammary tumor cells, LIF-induced Stat3 activation preserves the pro-apoptotic role of this factor in non-tumorigenic mammary cells. This activity might be altered in more aggressive or less differentiated tumors by different causes that need to be analyzed in future experiments. However, our results imply that in the development of therapeutic strategies for blocking Stat3 in breast cancer cells, the strong dependence on the cellular context that this factor activity displays should be taken into account.

\section{Conclusion}

The results presented here show that LIF is overexpressed in MMTV-induced mammary carcinomas, in which, as a paracrine/autocrine factor, it is the main one responsible for Stat3 activation. In well-differentiated mammary cancer cells, constitutive activation of Stat3 would therefore depend on LIF and LIF-R expression, as occurs in normal mammary epithelium. However, in these cancer cells, LIF induces cell survival through signaling pathways that would not involve Stat3 activation.

\section{Competing interests}

The authors declare that they have no competing interests.

\section{Authors' contributions}

$\mathrm{AQ}$ conducted the experiments in culture, the immunoassays and the western blot analysis and assisted in writing the manuscript. CSL performed the RT-PCR and helped in drafting the manuscript. LR helped to perform the crystal violet assays and the RT-PCR of EBP. RPM helped design and perform the morphological and immunohistochemical studies. ECK designed and coordinated the experiments and wrote the final manuscript. All authors read and approved the final manuscript.

\section{Acknowledgements}

We are very grateful toDr Elisa Bal de Kier Joffe (Instituto Roffo, Buenos Aires, Argentina), for providing the LM3 and LMM3 cells, Dr Nancy Hynes (Friedrich Miescher Institute for Biomedical Research, Basel, Switzerland) for providing the HC11 cells and Dr Mina J. Bissell (Lawrence Berkeley National Laboratory, Berkeley, CA, USA) for providing the SCp2 cells. We also thank Dr Omar A. Coso for his helpful comments on the manuscript; Dr Alejandra Guberman for providing Cy3 antibody; and Mr Antonio Morales and Mr Hector Costa for their efficient technical assistance. This work was supported by the Fogarty International Center, National Institutes of Health, USA (grant R01TW006212 to ECK), and by the Fundación Antorchas and CONICET, Argentina.

\section{References}

1. Gearing DP, Gough NM, King JA, Hilton DJ, Nicola NA, Simpson RJ, Nice EC, Kelso A, Metcalf D: Molecular cloning and expression of cDNA encoding a murine myeloid leukaemia inhibitory factor (LIF). EMBO J 1987, 6:3995-4002.

2. Taga T, Kishimoto T: Gp130 and the interleukin-6 family of cytokines. Annu Rev Immunol 1997, 15:797-819.

3. Dhingra K, Sahin A, Emami K, Hortobagyi GN, Estrov Z: Expression of leukemia inhibitory factor and its receptor in breast cancer: a potential autocrine and paracrine growth regulatory mechanism. Breast Cancer Res Treat 1998, 48:165-174.
4. Kellokumpu-Lehtinen $\mathrm{P}$, Talpaz M, Harris D, Van Q, Kurzrock R, Estrov Z: Leukemia-inhibitory factor stimulates breast, kidney and prostate cancer cell proliferation by paracrine and autocrine pathways. Int J Cancer 1996, 66:515-519.

5. Bamberger AM, Thuneke I, Schulte HM: Differential regulation of the human 'leukemia inhibitory factor' (LIF) promoter in T47D and MDA-MB 231 breast cancer cells. Breast Cancer Res Treat 1998, 47:153-161.

6. Estrov Z, Samal B, Lapushin R, Kellokumpu-Lehtinen P, Sahin AA Kurzrock R, Talpaz M, Aggarwal BB: Leukemia inhibitory factor binds to human breast cancer cells and stimulates their proliferation. J Interferon Cytokine Res 1995, 15:905-913.

7. Gearing DP, Thut CJ, VandeBos T, Gimpel SD, Delaney PB, King J, Price V, Cosman D, Beckmann MP: Leukemia inhibitory factor receptor is structurally related to the IL- 6 signal transducer, gp130. EMBO J 1991, 10:2839-2848.

8. Gearing DP, Comeau MR, Friend DJ, Gimpel SD, Thut CJ, McGourty J, Brasher KK, King JA, Gillis S, Mosley B, et al:: The IL6 signal transducer, gp130: an oncostatin M receptor and affinity converter for the LIF receptor. Science 1992, 255:1434-1437.

9. Darnell JE Jr: STATs and gene regulation. Science 1997, 277:1630-1635.

10. Raz R, Durbin JE, Levy DE: Acute phase response factor and additional members of the interferon-stimulated gene factor 3 family integrate diverse signals from cytokines, interferons, and growth factors. J Biol Chem 1994, 269:24391-24395.

11. Lutticken C, Wegenka UM, Yuan J, Buschmann J, Schindler C, Ziemiecki A, Harpur AG, Wilks AF, Yasukawa K, Taga T, et al.: Association of transcription factor APRF and protein kinase Jak1 with the interleukin-6 signal transducer gp130. Science 1994, 263:89-92.

12. Li M, Liu X, Robinson G, Bar-Peled U, Wagner KU, Young WS, Hennighausen L, Furth PA: Mammary-derived signals activate programmed cell death during the first stage of mammary gland involution. Proc Natl Acad Sci USA 1997, 94:3425-3430.

13. Chapman RS, Lourenco PC, Tonner E, Flint DJ, Selbert S, Takeda K, Akira S, Clarke AR, Watson CJ: Suppression of epithelial apoptosis and delayed mammary gland involution in mice with a conditional knockout of Stat3. Genes Dev 1999, 13:2604-2616

14. Li L, Shaw PE: Autocrine-mediated activation of STAT3 correlates with cell proliferation in breast carcinoma lines. J Biol Chem 2002, 277:17397-17405

15. Garcia R, Bowman TL, Niu G, Yu H, Minton S, Muro-Cacho CA, Cox CE, Falcone R, Fairclough R, Parsons S, et al:: Constitutive activation of Stat3 by the Src and JAK tyrosine kinases participates in growth regulation of human breast carcinoma cells. Oncogene 2001, 20:2499-2513.

16. Burke WM, Jin X, Lin HJ, Huang M, Liu R, Reynolds RK, Lin J: Inhibition of constitutively active Stat3 suppresses growth of human ovarian and breast cancer cells. Oncogene 2001 20:7925-7934.

17. Schere-Levy C, Buggiano V, Quaglino A, Gattelli A, Cirio MC, Piazzon I, Vanzulli S, Kordon EC: Leukemia inhibitory factor induces apoptosis of the mammary epithelial cells and participates in mouse mammary gland involution. Exp Cell Res 2003, 282:35-47.

18. Kritikou EA, Sharkey A, Abell K, Came PJ, Anderson E, Clarkson $\mathrm{RW}$, Watson CJ: A dual, non-redundant, role for LIF as a regulator of development and STAT3-mediated cell death in mammary gland. Development 2003, 130:3459-3468.

19. Minami M, Inoue M, Wei S, Takeda K, Matsumoto M, Kishimoto T, Akira S: STAT3 activation is a critical step in gp130-mediated terminal differentiation and growth arrest of a myeloid cell line. Proc Natl Acad Sci USA 1996, 93:3963-3966.

20. Kodama H, Fukuda K, Pan J, Makino S, Baba A, Hori S, Ogawa S: Leukemia inhibitory factor, a potent cardiac hypertrophic cytokine, activates the JAK/STAT pathway in rat cardiomyocytes. Circ Res 1997, 81:656-663.

21. Boeuf H, Hauss C, Graeve FD, Baran N, Kedinger C: Leukemia inhibitory factor-dependent transcriptional activation in embryonic stem cells. J Cell Biol 1997, 138:1207-1217.

22. Jenab S, Morris PL: Testicular leukemia inhibitory factor (LIF) and LIF receptor mediate phosphorylation of signal transducers and activators of transcription (STAT)-3 and STAT-1 and induce c-fos transcription and activator protein-1 activation in 
rat Sertoli but not germ cells. Endocrinology 1998, 139:1883-1890.

23. Cheng JG, Chen JR, Hernandez L, Alvord WG, Stewart CL: Dual control of LIF expression and LIF receptor function regulate Stat3 activation at the onset of uterine receptivity and embryo implantation. Proc Natl Acad Sci USA 2001, 98:8680-8685.

24. Buggiano V, Levy CS, Gattelli A, Cirio MC, Marfil M, Nepomnaschy I, Piazzon I, Helguero L, Vanzulli S, Kordon EC: Origin and progression of pregnancy-dependent mammary tumors induced by new mouse mammary tumor virus variants. Breast Cancer Res Treat 2002, 75:191-202.

25. Gattelli A, Cirio MC, Quaglino A, Schere-Levy C, Martinez N, Binaghi M, Meiss RP, Castilla LH, Kordon EC: Progression of pregnancy-dependent mouse mammary tumors after long dormancy periods. Involvement of Wnt pathway activation. Cancer Res 2004, 64:5193-5199.

26. Puricelli L, Colombo LL, Bal de Kier Joffe E, de Lustig ES: Invasiveness in vitro of two mammary adenocarcinoma tumors with different metastasizing ability. Invasion Metastasis 1984, 4:238-246.

27. Park JI, Strock CJ, Ball DW, Nelkin BD: The Ras/Raf/MEK/extracellular signal-regulated kinase pathway induces autocrineparacrine growth inhibition via the leukemia inhibitory factor/ JAK/STAT pathway. Mol Cell Biol 2003, 23:543-554.

28. Golubovskaya VM, Gross S, Kaur AS, Wilson RI, Xu LH, Yang XH, Cance WG: Simultaneous inhibition of focal adhesion kinase and SRC enhances detachment and apoptosis in colon cancer cell lines. Mol Cancer Res 2003, 1:755-764.

29. Bradford MM: A rapid and sensitive method for the quantitation of microgram quantities of protein utilizing the principle of protein-dye binding. Anal Biochem 1976, 72:248-254.

30. Lopez-Marure R, Gutierrez G, Mendoza C, Ventura JL, Sanchez L, Reyes Maldonado E, Zentella A, Montano LF: Ceramide promotes the death of human cervical tumor cells in the absence of biochemical and morphological markers of apoptosis. Biochem Biophys Res Commun 2002, 293:1028-1036.

31. Gattelli A, Zimberlin MN, Meiss RP, Castilla LH, Kordon EC: Selection of early-occurring mutations dictates hormoneindependent progression in mouse mammary tumor lines. $J$ Virol 2006, 80:11409-11415.

32. Haines BP, Voyle RB, Pelton TA, Forrest R, Rathjen PD: Complex conserved organization of the mammalian leukemia inhibitory factor gene: regulated expression of intracellular and extracellular cytokines. J Immunol 1999, 162:4637-4646.

33. Hutt JA, O'Rourke JP, DeWille J: Signal transducer and activator of transcription 3 activates CCAAT enhancer-binding protein delta gene transcription in GO growth-arrested mouse mammary epithelial cells and in involuting mouse mammary gland. $J$ Biol Chem 2000, 275:29123-29131.

34. Zhao L, Hart S, Cheng J, Melenhorst JJ, Bierie B, Ernst M, Stewart C, Schaper F, Heinrich PC, Ullrich A, et al:: Mammary gland remodeling depends on gp130 signaling through Stat3 and MAPK. J Biol Chem 2004, 279:44093-44100.

35. Catalano RD, Johnson MH, Campbell EA, Charnock-Jones DS, Smith SK, Sharkey AM: Inhibition of Stat3 activation in the endometrium prevents implantation: a nonsteroidal approach to contraception. Proc Natl Acad Sci USA 2005, 102:8585-8590.

36. Bharti AC, Donato N, Aggarwal BB: Curcumin (diferuloylmethane) inhibits constitutive and IL-6-inducible STAT3 phosphorylation in human multiple myeloma cells. J Immunol 2003, 171:3863-3871.

37. $\mathrm{Yu} \mathrm{H}$, Jove R: The STATs of cancer - new molecular targets come of age. Nat Rev Cancer 2004, 4:97-105.

38. Buettner R, Mora LB, Jove R: Activated STAT signaling in human tumors provides novel molecular targets for therapeutic intervention. Clin Cancer Res 2002, 8:945-954.

39. Badache A, Hynes NE: Interleukin 6 inhibits proliferation and, in cooperation with an epidermal growth factor receptor autocrine loop, increases migration of T47D breast cancer cells. Cancer Res 2001, 61:383-391.

40. Mora LB, Buettner R, Seigne J, Diaz J, Ahmad N, Garcia R, Bowman T, Falcone R, Fairclough R, Cantor A, et al.: Constitutive activation of Stat3 in human prostate tumors and cell lines: direct inhibition of Stat3 signaling induces apoptosis of prostate cancer cells. Cancer Res 2002, 62:6659-6666.
41. Catlett-Falcone R, Landowski TH, Oshiro MM, Turkson J, Levitzki A, Savino R, Ciliberto G, Moscinski L, Fernandez-Luna JL, Nunez $\mathrm{G}$, et al.: Constitutive activation of Stat3 signaling confers resistance to apoptosis in human U266 myeloma cells. Immunity 1999, 10:105-115.

42. Berishaj M, Gao SP, Ahmed S, Leslie K, Al-Ahmadie H, Gerald WL, Bornmann W, Bromberg JF: Stat3 is tyrosine-phosphorylated through the interleukin-6/glycoprotein 130/Janus kinase pathway in breast cancer. Breast Cancer Res 2007, 9:R32.

43. Zhao L, Melenhorst JJ, Hennighausen L: Loss of interleukin 6 results in delayed mammary gland involution: a possible role for mitogen-activated protein kinase and not signal transducer and activator of transcription 3. Mol Endocrinol 2002, 16:2902-2912.

44. Ling X, Arlinghaus RB: Knockdown of STAT3 expression by RNA interference inhibits the induction of breast tumors in immunocompetent mice. Cancer Res 2005, 65:2532-2536.

45. Selander KS, Li L, Watson L, Merrell M, Dahmen H, Heinrich PC Muller-Newen G, Harris KW: Inhibition of gp130 signaling in breast cancer blocks constitutive activation of Stat3 and inhibits in vivo malignancy. Cancer Res 2004, 64:6924-6933.

46. Dolled-Filhart M, Camp RL, Kowalski DP, Smith BL, Rimm DL: Tissue microarray analysis of signal transducers and activators of transcription 3 (Stat3) and phospho-Stat3 (Tyr705) in nodenegative breast cancer shows nuclear localization is associated with a better prognosis. Clin Cancer Res 2003, 9:594-600.

47. Puricelli L, Proiettii CJ, Labriola L, Salatino M, Balana ME, Aguirre Ghiso J, Lupu R, Pignataro OP, Charreau EH, Bal de Kier Joffe E, et al:: Heregulin inhibits proliferation via ERKs and phosphatidyl-inositol 3-kinase activation but regulates urokinase plasminogen activator independently of these pathways in metastatic mammary tumor cells. Int J Cancer 2002, 100:642-653.

48. Bromberg J: Stat proteins and oncogenesis. J Clin Invest 2002, 109:1139-1142.

49. Lu C, Kerbel RS: Interleukin-6 undergoes transition from paracrine growth inhibitor to autocrine stimulator during human melanoma progression. J Cell Biol 1993, 120:1281-1288.

50. Ball RK, Friis RR, Schoenenberger CA, Doppler W, Groner B: Prolactin regulation of beta-casein gene expression and of a cytosolic 120-kd protein in a cloned mouse mammary epithelial cell line. EMBO J 1988, 7:2089-2095.

51. Danielson KG, Oborn CJ, Durban EM, Butel JS, Medina D: Epithelial mouse mammary cell line exhibiting normal morphogenesis in vivo and functional differentiation in vitro. Proc Natl Acad Sci USA 1984, 81:3756-3760.

52. Desprez PY, Hara E, Bissell MJ, Campisi J: Suppression of mammary epithelial cell differentiation by the helix-loop-helix protein Id-1. Mol Cell Biol 1995, 15:3398-3404. 